\title{
ІННОВАЦІї
}

UDC 316.776:17.022.1(477)

L. M. Hanushchak-Efimenko, Doctor of Economic Sciences, Associate Professor, V. V. Kaplun, Doctor of Technical Sciences, Professor,

V. G. Shcherbak, Doctor of Economic Sciences, Professor

\section{RESOURCE- INNOVATIVE MODEL OF RAISING UNIVERSITY AUTONOMY}

Urgency of the research. The importance of expanding university autonomy was and remains one of the priorities of educational policy of Ukraine, the main precondition for universities to integrate Ukraine into the global academic community.

Target setting. Reasonable is the development and practical implementation of resource- innovative models of raising autonomy level of higher education institutions to enhance the independence and accountability of the University in decision making of academic freedom, organization of educational process, research, internal management.

Actual scientific researches and issues analysis. Scientific works of world scientists I. Gryshchenko, I. Kalenyuk, M. Gladchenko, A. Bernasconi, M. Brennan, A. Wall, P. McGowan, J. Chrisman, T. Hynes, S. Fraser, D. De Zilwa, K. Debackere, R. Veugelers, D. Dill, P.-K. Wong, Y.-P. Ho, A. Singh consider different aspects of autonomy of higher educational institutions.

Uninvestigated parts of general matters defining. Scientists have not worked out questions about enhancing university autonomy by using entrepreneurial approaches to its management.

The research objective. Article is aimed at justifying optimization program of the university autonomy through the use of this resources-innovative model.

The statement of basic materials. Autonomy acts as a condition of implementing innovative and intellectual potential, promotes the effective implementation of the mission and the vision, objectives and functions. The proposed threedimensional strategic matrix of program optimization of university autonomy by the method of game theory, the use of $A B C$-analysis as a method of ranking university autonomy program components by various parameters, developed forecast trend of options of autonomy optimization program of the university.

Conclusions. The implementation of resource-innovation model as alternative of academic (university) entrepreneurship would allow Ukrainian universities to move to a new type of commercially-oriented business relations on the principles of market economy, develop academic - educational, scientific, design and engineering work.

Keywords: autonomy of the university; strategic matrix; optimization; method of game theory; $A B C$-analysis; universities.
УДК 316.776:17.022.1(477)

л. М. Ганущак-Єфіменко, д. е. н., доцент,

В. В. Каплун, д. т. н., профресор,

В. Г.Щербак, д. е. н., профресор

\section{РЕСУРСО-ІННОВАЦІЙНА МОДЕЛЬ ПІДВИЩЕННЯ РІВНЯ АВТОНОМІї ВИЩИХ НАВЧАЛЬНИХ ЗАКЛАДІВ}

Актуальність теми дослідження. Важливість розширення університетської автономії було і залишається одним із пріоритетів освітньої політики України, головною передумовою інтеграції університетів України до світової академічної спільноти.

Постановка проблеми. Доцільним $є$ розробка та практичне впровадження ресурсо-інноваційної моделі підвищення рівня автономії вищих навчальних закладів з метою підвищення рівня самостійності, незалежності та відповідальності університету в прийнятті рішень відносно розвитку академічних свобод, організації освітнього процесу, наукових досліджень, внутрішнього управління.

Аналіз останніх досліджень і публікацій. Наукові праці світових вчених І. Грищенко, І. Каленюк, М. Гладченко, A. Bernasconi, M. Brennan, A. Wall, P. McGowan, J. Chrisman, T. Hynes, S. Fraser, D. De Zilwa, K. Debackere, R. Veugelers, D. Dill, P.-K. Wong, Y.-P. Ho, A. Singh розглядають різні аспекти автономності вищих навчальних закладів.

Виділення недосліджених частин загальної проблеми. Науковцями ще недостатньо опрацьовані питання підвищення рівня автономії університетів за рахунок використання підприємницьких підходів до його управління.

Постановка завдання. Стаття покликана обгрунтувати програму оптимізації автономії університету за рахунок використання запропонованої ресурсоінноваційної моделі.

Викладення основного матеріалу. Автономія виступає умовою реалізації інтелектуально інноваційного потенціалу, сприяє ефрективному здійсненню місії та бачення, завдань та функцій. Запропонована тривимірна стратегічна матриия оптимізації програми автономії університету методом теорії ігор, використання $A B C$ аналізу як методу ранжирування складових програми автономії університету за різними параметрами, розроблений прогнозний тренд варіантів оптимізації програми автономії університету.

Висновки. Впровадження ресурсо-інноваційної моделі як варіанту академічного (університетського) підприємництва дозволить перейти українським ВНЗ до нового типу комерційно-орієнтованих підприємницьких відносин на принципах ринкової економіки, розвинути академічну освітню, наукову, проектно-конструкторську та інженерно-технічну діяльність.

Ключові слова: автономія університету; стратегічна матриця; оптимізація; метод теорії ігор; $A B C$ аналіз; вищі навчальні заклади. 


\section{ІННОВАЦII}

Formulation of the problem. In terms of post-Soviet, transformation processes in the center of the study were the issue of the current situation in education. Over the past two decades due to changing of social and economic conditions in the global academic community increasingly growing awareness of the inevitability of organizational and managerial transformation of higher education. This need has become even more apparent after the dramatic geopolitical changes and completing the process of converting post-industrial society in the global community, characterized by a single information space. Education is currently under a structural crisis. The ineffectiveness of the existing model of the university in the realities of the global space market economy was evident for much of the staff of higher education institutions (HEls) and researchers in the West and in Ukraine. Due to reduced funding of education by government and market expansion of educational services in higher education it was necessary to improve management, increase the competitiveness of universities by improving their competitive advantages and business development.

Analysis of recent research and unsolved part of the problem. The expansion of university autonomy was and remains one of the priorities of educational policy in Ukraine. The question of expanding the autonomy of universities as a factor of increasing their competitiveness was studied by many scientists who suggest that the modern economy itself becomes the economy, based on knowledge (moving knowledge) that the boundaries between education and the economy are blurring and disappear [5, 9 and others.]. The study of various components of the autonomy of universities and their influence on the process involved works of: I. Kaleniuk [13] - through models of financial autonomy of universities in different countries, M. Gladchenko [14] - based on the introduction of the concept of the university as an organizational entity; I. Gryshchenko [5] - the concept of entrepreneurial research university; A. Romanovsky [4] - concept of university (academic) business. The study of the phenomenon of innovation and business transformation, impressive success of entrepreneurial universities abroad shows that one of the main ways of increasing the efficiency and quality of educational and research activities, to improve the financial condition and competitiveness on the global education market is a collective enterprise, particularly in circumstances where decentralization colleges and universities increases [1-4; 11-13].

The main features and components of University business autonomy is an innovative entrepreneurial vision, will and concerted efforts of university directorate, as well as good corporate entrepreneurial culture of the staff.

Lack of consistency of existing theoretical and practical approaches in the study of autonomy and entrepreneurial aspects of universities, ranking factors that have the greatest impact on competitive advantage, leads to the fact that many problems remain unsolved, controversial and require further study.

Aim of the article is to develop a resource-innovation model that would enhance the autonomy of higher education institutions, the implementation of which will strengthen the role of entrepreneurship and corporate entrepreneurship culture in the process of entrepreneurial universities.

Research results. One of the main problems of reforming the Ukrainian system of higher education is to determine the form and extent of the autonomy of universities to ensure their effectiveness and maintain a balance between the degree of autonomy and state control of educational process in order to adequately meet social expectations, including a combination of free-market ideology with the principles of social justice.

The problems of university autonomy is extremely relevant for Ukraine during active reforming of the national higher education system. That which sought national universities seeking compromise with the Ministry of Education and Science of Ukraine in matters of university autonomy, it is now really solvable problem. The adoption of the new Law of Ukraine "On Higher Education", which expanded the rights and responsibilities of universities eased pressure of centralized management, simplified the licensing procedure of educational activities and accreditation of educational programs, changed the vector of national higher education.

When management functions of universities are concentrated in public institutions, happens tough unification of training, which narrows their professional horizons, reduces the flexibility of response of education to labor market demand and so on. In case of transfer of administrative functions to aca- 


\section{ІННОВАЦІї}

demic structures, there is a threat of universities to become isolated from society. International and European documents propose to solve this dilemma by strengthening public control over the quality of education, optimization and decentralization of certain higher education. "Higher education institutions must be given autonomy in their internal affairs, but this autonomy should be accompanied by clear and transparent accountability to the government, parliament, students and society as a whole" [15].

One solution to this problem is to expand the resource base for the establishment and development of innovative entrepreneurial university. Resource approach or RBV definition of university autonomy is an account of the synergistic impact of institutional, human, financial and commercial factors in this process. Hence the basic functional tasks effectively use the resources of academic institutions as multi-organizational and methodical academic, scientific and economic system with the release of the main components: organizational and methodical; economic and financial; scientific and educational; engineering; entrepreneurial and business (Fig. 1).
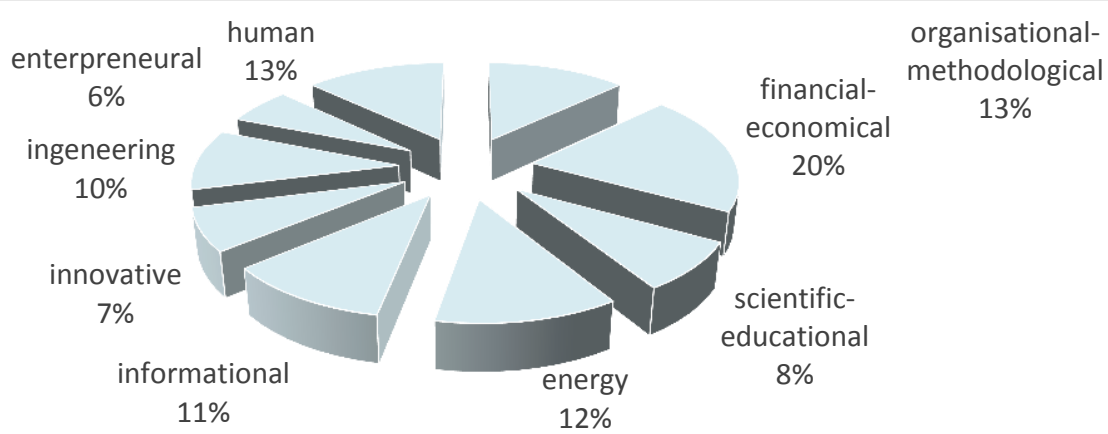

Fig. 1. Ratio of university resources as multi-organizational and methodical academic, scientific and economic system

Generalized by authors

Analysis of the ratio of implications of different types of resources in all manufacturing processes of Universities (education, teaching, research, economic and entrepreneurial) allowed to come to the conclusion that the most effective form of autonomy control can be represented as a multidimensional structure that can increase the autonomy of the university and its ability to respond quickly to changing internal and external conditions (Fig. 2). This is accomplished by identifying individual functional components and resources that affect the ability to provide competitively priced educational services to a level of quality that consumers need. This approach creates competition within the university for the right to bring to the production process the necessary resources, and the need to find ways to further business search that implement the principles of management autonomy in the internal environment of the university. To find the best way for the university development it is necessary to choose the most effective program of optimization of its autonomy level. Development and optimization of the program should be based on the determination of the ratio of used and unused / types of services offered, the types of resources, functional units, types of customers (Fig. 2).

Clearly, the system of autonomy of innovative entrepreneurial university - is not a panacea, but the opportunity to make a difference. Only an integrated, differentiated impact on staff and management, with taking into account the social, psychological and economic conditions can change the culture of the organization, people look at the problem of competitiveness, development of competitive advantages. Formation of the organization's mission, ideology, organizational culture, determination of leaders able to lead the staff, the disclosure of potential employees for the continuous improvement of the university require special attention, or rather, their impact on the social component. Choosing an effective autonomy of the university - is primarily a problem of management. Task of the management company - to create all conditions for personnel (considering its features) to achieve its goals, while minimizing the negative effects of possible conflicts inherent in any adaptation process. 


\section{ІННОВАЦІї}

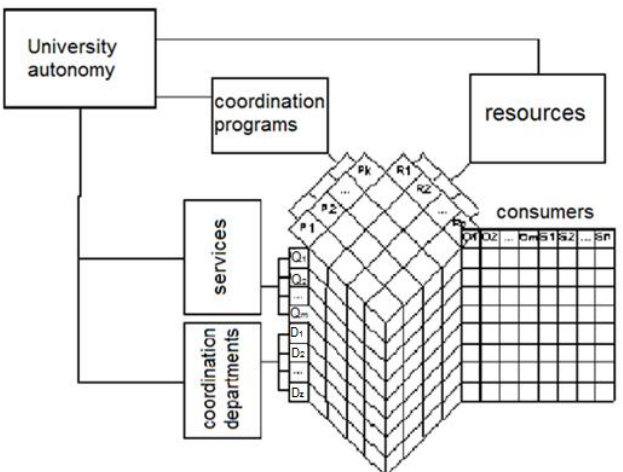

Marks: Pk - University autonomy optimization program; Rm - types of resources; Sp - University services consumers; $Q n$ - University types of service; Dz - functional departments of the university.

Proposed by authors

\section{Fig. 2. Three-dimensional organizational structure of autonomous universities}

The approach of optimization of university autonomy is based on the use of selection criteria (of the most appropriate program - autonomy factor):

$$
K_{\text {aem }}=\frac{\Sigma Q_{i j z}}{\Sigma R_{i j z}} \rightarrow \max
$$

$Q_{i j z}$-the volume of university educational services obtained by $i$ educational program, of $j$ degree by $z$ functional unit; $R_{i j z}$ - resources spent by university on providing educational services and educational program by i educational program, of $j$ degree by $z$ functional unit.

Since the problem of finding the optimal program to enhance the autonomy of the university's multidimensional view, its implementation is possible through methods of linear programming or the method of game theory. Using game theory is most appropriate because it requires the presence of 2 players. In this case, the first player (Player A) - a university that is committed to provide the maximum amount of educational services at the maximum price while spending a minimum of resources, the second player - consumer of services - applicants, students, masters, postgraduate, etc. (player) who is seeking for educational services at the lowest cost and maximum quality. As can be seen from this strategy players of the task are in antagonism - in diametrically opposite direction. Solution of the pair of these dual problems is as follows:

Player A (maximizing the volume of service for minimum resources spent) selects strategy of Maximin as follows:

$$
\left.\max _{p i}\left\{\min \left(\sum_{i=1}^{n} a_{i 1} x_{i}, \sum_{i=1}^{n} a_{i 2} x_{i} \cdots \sum_{i=1}^{n} a_{i n} x_{i}\right)\right)\right\},
$$

Player B (minimizing resource costs for services for Maximin quality) at Minimax principle:

$$
\min _{p j}\left\{\max \left(\sum_{j=1}^{m} a_{j 1} y_{j}, \sum_{j=1}^{m} a_{j 2} y_{j} \ldots \sum_{j=1}^{m} a_{j n} y_{j}\right)\right\},
$$

$x i$-the probability of selecting $i$ strategies of University behavior (volumes of educational services), $y j$ - the probability of choosing $j$ strategy of consumer behavior (spendings for education services).

When solving the tasks of Maximin / Minimax by game theory in the formation of optimal programs of enhancing the autonomy, the University can receive guidance for setting the optimal level of educational services, which also allows to get the maximum service delivery and minimum resource costs for 


\section{ІННОВАЦІї}

each of the possible types of educational services (educational programs) . In general, the strategy matrix will have a three-dimensional look - Figure 3.

In each plane (i; j) of three-dimensional strategy matrix, selection of the most appropriate program of university autonomy on the basis of maximizing the volume of educational services (axis OX) / minimizing resource costs (axis OY) is proposed to use the method of Pareto (ABC-analysis), which allows you to find the main point of leverage (in terms of strengthening the autonomy of the university).

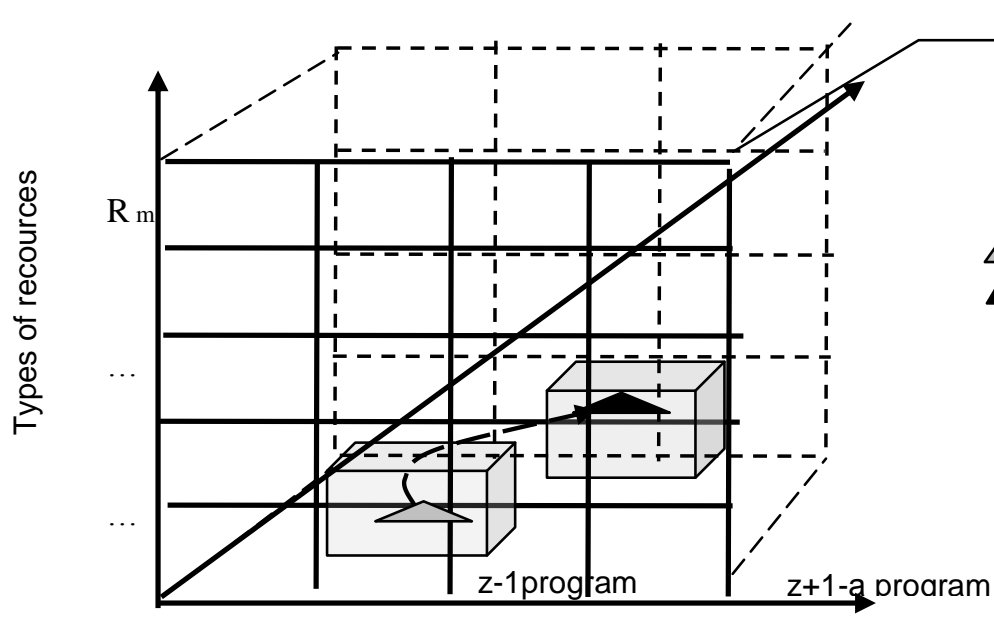
Vector of optimiza-
tion program of universi-
ty autonomy

Q $1 \quad$ Q 2

Q n

Fig. 3. The three-dimensional matrix of strategic optimization of program of university autonomy Proposed by authors

Using the ABC-method in our study proved that it allows you to classify resources according to their impact on the result (the volume of educational services). To do this, ABC-analysis is necessary to divide the factors into three categories: 1) A - the most powerful $20 \%$ of resources can get $80 \%$ of the services; 2) B - intermediate: $30 \%$ of resources can get $15 \%$ of the services; 3 ) $C$ - the least powerful: $50 \%$ of resources can get $5 \%$ of services (Fig. 4).

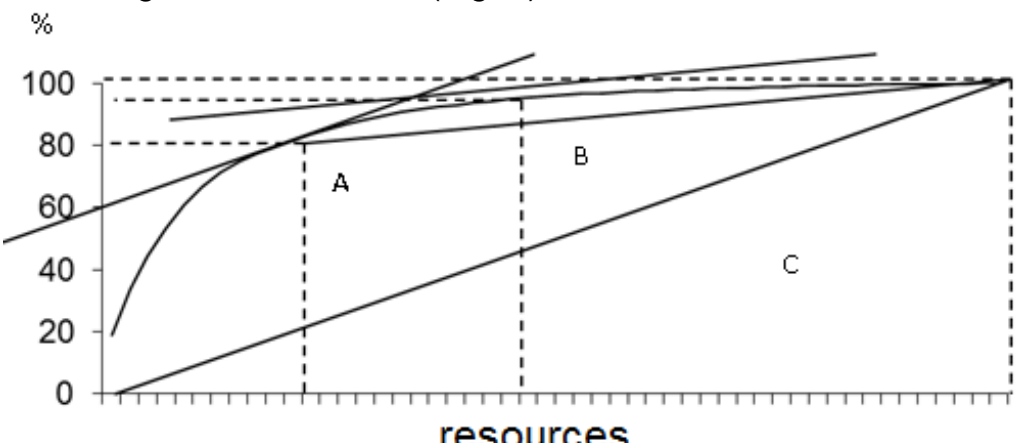

Fig. 4. Building cumulative curve for $A B C$-analysis

Proposed by authors

In fact, $A B C$-analysis - is a ranking of components of the program of universities autonomy on various parameters. The result of the $A B C$ analysis is a grouping of components of the program by the degree of influence on the overall result - the volume of educational services (in this case an indicator of operating Leverage). Transformation of a three-dimensional matrix of strategic optimization of program of university autonomy with the use of $A B C$ analysis can be represented as a matrix, where the 


\section{ІННОВАЦІї}

axis OX is "The volume of educational services"; the axis of the OY - indicator "Resources"; along the axis $\mathrm{OZ} \mathrm{-} \mathrm{an} \mathrm{indicator} \mathrm{of} \mathrm{"Leverage"} \mathrm{(Fig.} \mathrm{5).}$

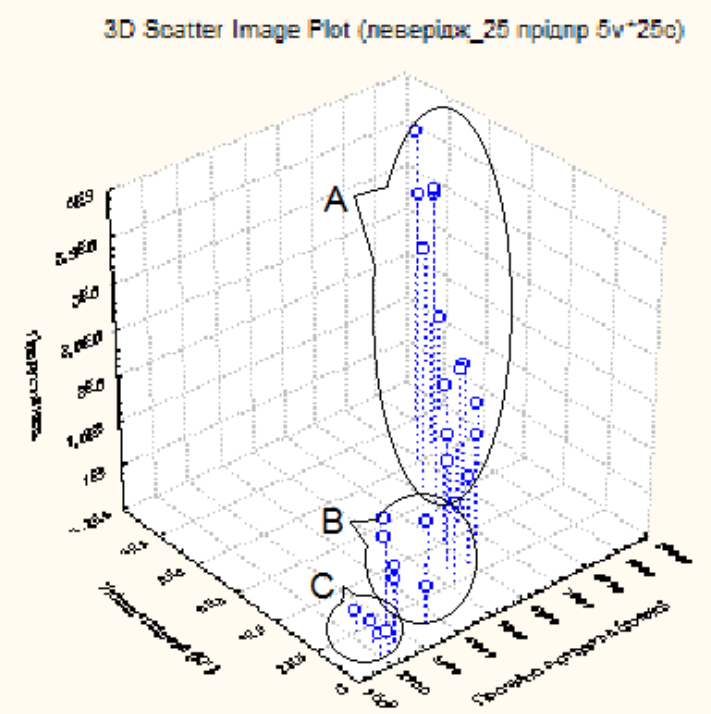

Fig. 5. Visualization of the procedures for determining the structure of components of the university autonomy program by $\mathrm{ABC}$-analysis

Calculated by authors using the program Expert Choice 2000

These calculations were performed using the software Expert Choice 2000 that allows to make a reasonable choice (in this case the structure of the components of the university autonomy program) of optimal according to specific criteria option.

For a more detailed analysis of the resulting evaluation of the program of university autonomy it is necessary to implement the so-called "cut" of the resulting three-dimensional matrix (in the axis $\mathrm{OZ}$ an indicator of "Leverage") to determine which factors have on the Pareto principle greatest impact on the result of the university activity - the volume of educational services (Fig. 6).

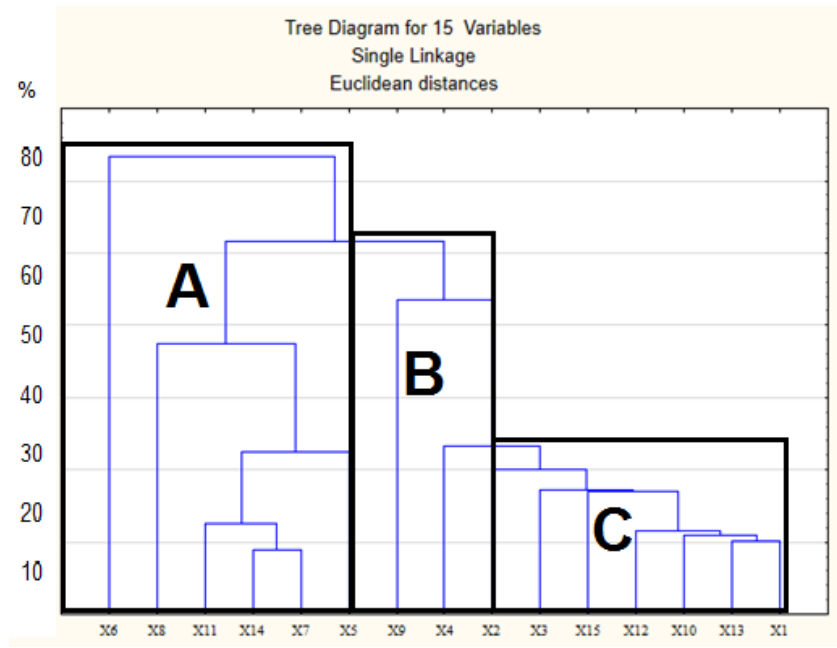

Fig. 6. "Cut" of the resulting three-dimensional matrix (in the axis $\mathrm{OZ}$ - an indicator of "Leverage") Calculated by authors using the program Expert Choice 2000

As illustrated by Figure 6 to the "A" (first cluster) zone in which $20 \%$ of factors can get $80 \%$ of educational services, which got partial indicators: X6 (labor costs), X8 (R \& D expenditures), X11 (utility 


\section{ІННОВАЦII}

costs), H14 (external connections, the number of international grants received), $X 7$ (competence of the teaching staff), X5 (training costs); in the second cluster (zone "B") the result is affected by a smaller degree with an intermediate value of $30 \%$ of factors: $X 9$ (value of tangible assets of the university), X4 (value of intangible assets of the University), X2 (receiving degrees by scientific and teaching staff) which provide $15 \%$ of educational services. To the "C" were the least influential factors of $50 \%$ : X3 (cost of education), $\mathrm{H} 15$ (the cost of computerization), X12 (the cost of social services), X10 (costs of market research), $\mathrm{H} 13$ (advertising costs, pr-shares), $\mathrm{X} 1$ (health care costs), which provide $5 \%$ of educational services.

The results of the analysis of the impact of key factors on the main results of the educational activities of the university confirmed the theoretical conclusions about the dependence of reasonable program of autonomy from the change of the partial indicators, including resource costs, reflecting not just their sheer size, but also their quality content, in particular - the cost of increasing the quality of science -teaching level - competence, qualification, research and more. This confirms the forecast trend of optimization program options of University autonomy (Fig. 7).

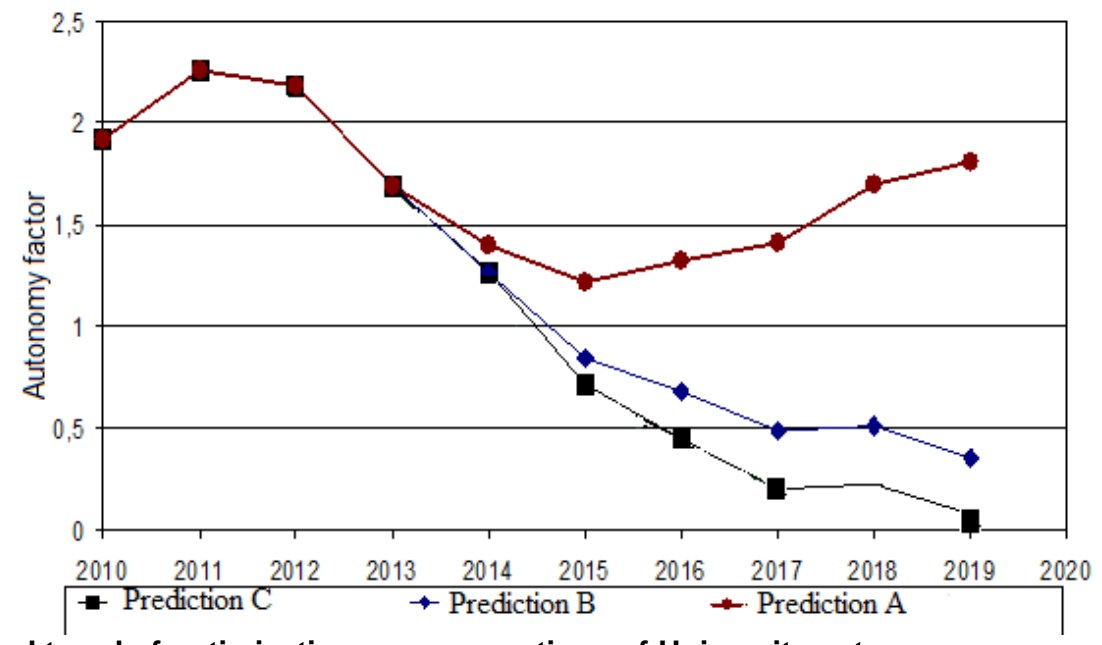

Fig. 7. Projected trend of optimization program options of University autonomy

Calculated by authors using the program Expert Choice 2000

Forecast A - optimistic ratio of the most influential factors affecting the rate of autonomy (20:30:50); forecast $B$ - a realistic value of the most influential factors affecting the rate of autonomy (25:25:50); forecast $C$ - pessimistic ratio of the most influential factors affecting the rate of autonomy (30:20:50).

Conclusions and suggestions. University stays as higher education institution, which is making efforts to generate knowledge, transforming them into practice, new activities, systematic change and modification of the internal environment. Significant limitations in the aforementioned areas related to the lack of financial and information resources. In addition, a significant role in this process is the human factor. The use of the above resources is seen as a sign of business. However, without the presence of these resources, the business of the university is not possible, because the traditional universities solve the problem of resources as a problem which must be solved at the environment in which they operate. However, if it really happens, then the entrepreneurial potential of universities is significantly reduced.

Academic Capitalism is a newly-established form of entrepreneurship and commercialization of activities in the field of science, education, scientific and educational services under market conditions. The phenomenon of academic (university) business as a new type of commercially-oriented entrepreneurial university, is the result of penetration of market economy principles in purely academic - educational, scientific, design and engineering activities of the university. A large number of studies on the phenomenon of university entrepreneurship demonstrates the importance and effectiveness of entrepreneurial universities in the context of globalization and total commercialization of all spheres of human activity. A large variety of business models research confirms the effectiveness of their activities, 


\section{ІННОВАЦІї}

tangible progress in strengthening its financial condition and material base. Almost all research universities stand out for its entrepreneurial independence from funding sources, impact on the local economic growth, and some economic, scientific and technological achievements of nations. The positive experience of leading foreign business university is useful for studying conditions in the Ukrainian realities and can serve as a model of entrepreneurship and business activity for national universities, confirms the need for business cooperation of university (academic) science with industry (business) support for effective government.

\section{References}

1. Hrudzynskyy, A. O. (2004). Proektno-oryentyrovanniy unyversytet. Professyonal'naya predprynymatel'skaya orhanyzatsyya vuza. Monohrafyya. [Project-oriented university. Professional entrepreneurial organization of the university] N. Novhorod : NNHU Publishing, P. 370. [in Russian].

2. Itskovits, G., Uvarov, A. F. (2010). Troinaia spiral Universitety predpriiatiia gosudarstvo Innovatsii v deistvii monografiia [Triple Helix. Universities - Enterprises - State. Innovation in action : monographa. - Tomsk: Tomsk State University of Control Systems and Radioelectronics Publishing, P. 237 [in Russian].

3. Konstantynov, H. N., Fylonovych S. R. (2007). Chto takoe predprynymatelskyy unyversytet [What is the entrepreneurial university] Voprosy obrazovanyya, Education Issues, No. 1, pp. 49-62 [in Russian].

4. Romanovskyy, O. O. (2012). Fenomen pidpryyemnytstva $v$ universytetakh svitu : monohrafiya. [The phenomenon of entrepreneurship in universities around the world] Vinnytsya : Nova Knyha, P. 504 [in Ukrainian].

5. Hryshchenko, I. M., Breus, S. V., Khaustova, Ye. B. (2016). Zbalansovana systema pokaznykiv vyshchoho navchalnoho zakladu: vid zahalnoyi stratehiyi do pokaznykiv diyalnosti strukturnoho pidrozdilu [The balanced scorecard of the university from overall strategy to performance of the structural unit]. Visnyk Kyyivskoho natsionalnoho universytetu tekhnolohiy ta dyzaynu. Seriya "Ekonomichni nauky". No. 2 (97), pp. 43-62 [in Russian].

6. Bernasconi, A. University Entrepreneurship in a Developing Country: The Case of the P. Universidad Catolica de Chile, 1985-2000. // Higher Education, 2005. - Vol. 50. Is. 2. - pp. 247-274.

7. Brennan M. C., Wall A. P., McGowan, P. Academic Entrepreneurship. Assessing preferences in nascent entrepreneurs. // Journal of Small Business and Enterprise Development, 2005. - Vol. 12. - Is. 3. - pp. 307-322.

8. Chrisman, J., Hynes, T., Fraser, S. Faculty Entrepreneurship and Economic development: The Case of the University of Calgary. // Journal of Business Venturing, July 1995. - Volume 10. - Is. 4. - pp. 267-281.

9. De Zilwa D. Using Entrepreneurial Activities as a means of survival: Investigating the processes used by Australian Universities to diversify their revenue streams // Higher Education, 2005. - Vol. 50. - Is. 3. - pp. 387-411.

10. Debackere, K., Veugelers, R. The role of academic technology transfer organizations in improving industry science links. // Research Policy, 2005. - Vol. 34. - Is. 3. - pp. 321-342.

11. Dill, D. University-industry entrepreneurship: the organization and management of American university technology transfer units. // Higher Education, 1995. - Vol. 29, No. 4. - pp. 369-384 [in Russian].

12. Wong, P.-K., Ho, Y.-P., Singh, A. Towards an 'entrepreneurial university' model to support knowledge-based economic development: The case of the national university of Singapore. // World Development, 2007. - Vol. 35. - Is. 6.

\section{Література}

1. Грудзинский А. О. Проектно-ориентированный университет. Профессиональная предпринимательская организация ВУЗа: монография / А. О. Гудзинский. - Н. Новгород : ННГУ, 2004. - 370 с.

2. Ицковиц, Г. Тройная спираль. Университеты предприятия - государство. Инновации в действии: монография / Г. Ицковиц ; пер. с англ. под ред. А. Ф. Уварова. - Томск : изд-во Том. гос. ун-та систем упр. и радиоэлектроники, 2010. - 237 с

3. Константинов, Г. Н. Что такое предпринимательский университет / Г. Н. Константинов, С. Р. Филонович // Вопросы образования. - 2007. - № 1. - С. 49-62.

4. Романовський, О. О. Феномен підприємництва в університетах світу: монографія / О. О. Романовський. Вінниця : Нова Книга, 2012. - 504 с.

5. Грищенко, І. М. Збалансована система показників вищого навчального закладу: від загальної стратегії до показників діяльності структурного підрозділу / І.М.Грищенко, С. В. Бреус, Є. Б. Хаустова // Вісник Київського національного університету технологій та дизайну. Серія "Економічні науки". - 2016. - № 2 (97). - С. 43-62.

6. Bernasconi, A. University Entrepreneurship in a Developing Country: The Case of the P. Universidad Catolica de Chile, 1985-2000 / A. Bernasconi // Higher Education. 2005. - Vol. 50. - Is. 2. - Pp. 247-274.

7. Brennan, M. C. Academic Entrepreneurship. Assessing preferences in nascent entrepreneurs / M. C. Brennan, A. P. Wall, P. McGowan // Journal of Small Business and Enterprise Development, 2005. - Vol. 12. - Is. 3. - pp. 307-322.

8. Chrisman, J. Faculty Entrepreneurship and Economic development: The Case of the University of Calgary / J. Chrisman, T. Hynes, S. Fraser // Journal of Business Venturing, July. - Volume 10. - 1995. - Is. 4. - pp. 267-281.

9. De Zilwa D. Using Entrepreneurial Activities as a means of survival: Investigating the processes used by Australian Universities to diversify their revenue streams / De Zilwa D. // Higher Education. - 2005. - Vol. 50. - Is. 3. - pp. 387-411.

10. Debackere, K. The role of academic technology transfer organizations in improving industry science links / K. Debackere, R. Veugelers // Research Policy. - 2005. - Vol. 34. - Is. 3. - pp. 321-342.

11. Dill, D. University-industry entrepreneurship: the organization and management of American university technology transfer units / D. Dill // Higher Education. - 1995. - Vol. 29, No. 4. - pp. 369-384.

12. Wong, P.-K. Towards an 'entrepreneurial university' model to support knowledge-based economic development: The case of the national university of Singapore / Wong, P.K., Ho, Y.-P., Singh, A. // World Development. - 2007. - Vol. 35. - Is. 6. - pp. 941-958.

13. Каленюк, І. Диверсифікація джерел фрінансування освіти / І. Каленюк // Фінанси України. - 2007. - № 11. - С. $120-124$. 


\section{ІННОВАЦІї}

- pp. 941-958.

13. Kalenyuk, I. (2007). Dyversyfikatsiya dzherel finansuvannya osvity [Diversifying of sources of education funding]. Finansy Ukrayiny, No. 11, pp.120-124. .[in Ukrainian].

14. Hladchenko, M. (2013). Analiz adaptatsiinoi modeli stratehichnoho. menedzhmentu vyshchoi osvity [Analysis of adaptive strategic model. Higher Education Management]. Theory and methods of education management, Is. 10 Retrieved from: irbis-nbuv.gov.ua/cgi-bin/.../cgiirbis_64.exe? [in Ukrainian].

15. Khartiia universytetiv Ukrainy: akademichni svobody, universytetska avtonomiia ta osvita [Charter of Ukraine universities: academic freedom, university autonomy and education]. (2009). Education of Ukraine. Retrieved from : http://dspace.nbuv.gov.ua/handle/123456789/41050 Ukrainian].
14. Гладченко, М. Аналіз адаптаційної моделі стратегічного. менеджменту вищої освіти [Електронний ресурс] / М. Гладченко // Теорія та методика управління освітою. 2013. - Вип. 10. - Режим доступу : irbis-nbuv.gov.ua/cgibin/.../cgiirbis 64.exe?.

15. Хартія університетів України: академічні свободи, університетська автономія та освіта : [створена на Міжнар. конфр. “Ольвійський форум-2009” у Ялті 11-15 черв. 2009 р.] [Електронний ресурс] // Освіта України. - 2009. Режим доступу

http://dspace.nbuv.gov.ua/handle/123456789/41050.

Received for publication 19.01.2017

Бібліографічний опис для цитування :

Hanushchak-Efimenko, L. M. Resource-innovative model of raising university autonomy / L. M. Hanushchak-Efimenko, V. V. Kaplun, V. G. Shcherbak // Науковий вісник Полісся. - 2017. - № 1 (9). ч. 2. - С. 61-69. 